\title{
How to strike a balance in the qualities and skills about the university art education
}

\author{
Liu Xiang \\ Nanjing normal university Taizhou College \\ Taizhou, China \\ 554221709@qq.com
}

\author{
Sun Weiwei \\ Nanjing normal university Taizhou College \\ Taizhou, China \\ 85106639@qq.com
}

\begin{abstract}
By comparing the education connotation of college quality education and vocational and technical schools skills, analysis of four aspects reasons about advanced art education in quality and skills, and puts forward solutions from three aspects, expecting to develop useful talent for social and economic services.
\end{abstract}

Keywords-quality education; skills; education; and balance

\section{INTRODUCTION}

The current Chinese higher fine arts education mode to cultivate students form two phenomena: one is because the market knowledge and experience and less common in society can't find a job or can not adapt to the demand of the society and eliminated by the society; Another is too vulgar "money" phenomenon, the design works of copper bad smell is very strong, the lack of cultural taste. Two phenomena represent the imbalances exist in the fine arts education in the quality and skills training, this article will focus on analysis of four aspects: cause of the imbalance, and puts forward solutions from three aspects, expecting to develop useful talent for social and economic services.

\section{THE AIM OF HIGHER ARTS EDUCATION}

There's a phrase in Confucian classics "university", "the way of university, in clearly, in people, in goodness." Think "university" is the purpose of carrying forward aboveboard in human nature and moral character; make the person to achieve the most perfect state. Specifically mainly contains two aspects of content: the first is the professional education, in order to let the student through professional education, make some aspects of a specialist, and after graduation, can enter into a certain field, do some practical things for society, for the improvement of intelligence; Quality education is on the other hand, if the professional education is to impart knowledge, so the quality education is to teach students methods, is for the cultivation of emotional intelligence. Professional education is the foundation, so to speak, quality education is fundamental, teach students some skills is a necessary condition for survival, improve students' comprehension ability or flexible ability, and selfstudy ability is one instance for the ultimate goal of education.

In 1998, according to the ministry of education issued "specialty catalog and introduction of common colleges and universities", the "widening specialty caliber, thick foundation, multidisciplinary cross" under the guidance of the spirit, professional similar will ever play, ring arts, decoration, advertising, animation design, people, within the scope of the "art and design" will also not so similar clothing design, ceramic and metal technology, lacquer painting, fiber art and other special art and design "art" melt in a furnace. Form a higher fine arts research direction. [1]

With an emphasis on quality education and cultivate students' creative, adaptive and sustainable development; Encourage students to think positive, to give them sufficient to create space for students autonomy, protect the enthusiasm of students learning, automaticity; Will be teaching in the development of the dynamic process, the course content.

\section{IMBALANCE OF ART EDUCATION IN QUALITY EDUCATION AND PROFESSIONAL EDUCATION}

For a long time, because of contempt of normal education prejudice and normal university teachers' knowledge structure is unreasonable, the fine arts education especially higher education of fine arts, "professional art education, ordinary art education", "light heavy skill education, quality-oriented education", "light weight the cultivation of the artist, teacher training, teachers of fine arts colleges and universities and professional art colleges and universities gradually confusion, repeated investment, waste of money, training target fuzzy, graduates employment direction is not clear, professional engaged in has nothing to do with your major. [2]

\section{A. Influence of social environment and external employment}

College students left school after four years of higher education after entering the society, to directly into all walks of life related to the design, learned four years are going to test in practice, the value will be realized in practice. China's booming market economy has provided a broad space for them to display their abilities. However, the current situation of the current art design graduates is not so good. Although the current college students have rich cultural knowledge, but lack of the ability of hands-on practice, after entering society could not immediately put into working condition.

Based on the art of design patterns, has not set much store by contacts with the technology, economy and also doesn't consider the effect of economy to the design, follow this design pattern makes our country did a lot of the constraints of the 
development of modern art design [3]. From the entire education system and the design for the understanding of the design education for more than 20 years development, China's design is obvious in the "market affects" mode, rather than "thought affects", "social affects" mode. Until today, the design of domestic education although the surface is very busy, in fact in the education system and there is no essential difference in the early 1980 s. Many people think that adds some computer courses is the modernization of education, is just to learn a few software operation, the progress of social economy is not reflected from the art design education. [4]

\section{B. Art education pattern in our country}

Art design education in China has been the traditional way of teaching, emphasize the unity on the teaching mode and curriculum, emphasizes the regularization, the same; Emphasis on education is given priority to the class and the teacher's leading role, pay attention to basic skill training, and ignore students' art accomplishment, art training; Pay attention to students strictly in accordance with the requirements of the syllabus, according to the requirements of the teacher to complete assignments, and neglect developing students apply basic knowledge, active thinking ability to engage in artistic creation, Focuses on students' practice of the school classroom, has neglected the student's art practice activities; Pay attention to inheriting the existing fixed artistic conception, ignore the innovation of artistic development. [5]

\section{Quality of teachers and teachers needs to be improved}

In the industrialization and mercerization of education in art colleges admissions rapidly at the same time, the lack of teachers, teaching space and the insufficient education equipment, living facilities is difficult to adapt to, the graduate student employment difficulty. China fine arts education especially the expansion of the quantity of higher fine arts education is facing serious contradiction with high quality problem. Art education can not be one-sided pursuit of quantity expanding, especially should pay more attention to quality, or the volume of the expanded at the same time pay more attention to quality. The simple pay attention to the scale, pay attention to form, the practice of demanding uniformity, make the person is easy to think of "the great leap forward" movement at that time.

In art design education, the teachers in colleges and universities are undergraduates, master's and doctoral students proportion is very small. Severe teacher knowledge structure is not reasonable, and the specific historical conditions in our country teachers' professional knowledge structure can not fully meet the needs of the modern art design education. Embodied in the teaching, often on the basis of their original major, rarely consider the combination of the design professional with the need of modern design. Teachers rarely understand art design market, lack of initiative of comprehensive ability to use knowledge. Therefore will appear in the teaching the single teaching mode, don't pay attention to pragmatic, application design, and so on and so forth, cause the student to the knowledge in and passive acceptance, not through practice and independent creative ability will achieve mastery through a comprehensive knowledge. [6]
A serious shortage of teachers, for students majoring in arts design highlights on some of the new professional, such as animation professionals. Art design in colleges and universities teachers solve, in part, by their colleges and universities graduates teaches or introduce other art design colleges and universities graduates directly as a teacher, although this part of the teachers' degree is higher, now generally requires a master's degree or above, but the title on the low side, lack of experience in teaching, the teaching level be discounted; Others from fine arts career of art design, this part of the teachers use short-term training, more training or self-study way into art and design, no professional art design education, also do not have practice experience in art design, most people are hard to work of art and design teaching. [7]

\section{Influence of the students}

China since the 1980 s nearly 20 years time, the development trend of the fine arts education in general is good, but after the enrollment expansion of colleges and universities has brought such as lack of teachers and students the decline in the quality and unreasonable subject setting, the admissions process for private fraud and a series of new problems

In recent years, Chinese higher fine arts education in an unprecedented and admissions frenzy, many governments art schools, the comprehensive university or professional school are fine arts, fine arts enrollment rise sharply, enter oneself for an examination the boom of art colleges and universities become the one big landscape of the contemporary China. Higher fine arts education to expand in the fine arts education of primary and secondary schools and society in the continuing education has caused a chain reaction. Many schools and parents send a child to enter oneself for an examination the art colleges and universities as a way out of the entrance, there are even "students with poor grades to enter oneself for an examination art academy" bias. Universities and colleges in the art design, students mainly come from the fresh and old high school graduates, and most of all is the school of arts living. Through 3 months or more so-called "intensive training" for a short period of time, was rushed to the battle, to go to art college, made art and design professional college cultural quality low examinee's "spike". Many students did not love for art, lack the necessary basic knowledge before entering the art college, more impossible to deep love of art, like purgatory to go to school. Eventually lead to lower cultural quality of students, the overall artistic level is not high; many students lack of consciousness and perseverance, the psychological quality is very poor, the love of ease, low expectations, laidback, group cooperation consciousness, independent thinking ability is very weak.

\section{NATIONAL POLICY ORIENTATION}

According to the news website of the Ministry of education, Ministry of Education recently issued "on doing a good job in 2015 national college graduates employment work notice" (hereinafter referred to as the "Circular") and "Circular" pointed out that the 2015 macro employment situation facing multiple pressures, further increase the scale of college graduates, employment work task very arduous. 
One is to comprehensively promote innovation and entrepreneurship education and independent entrepreneurship. All colleges and universities to the innovation and entrepreneurship education as promote an important starting point for the comprehensive reform of higher education, innovation and entrepreneurship education through personnel training process, open innovation and entrepreneurship education specialized courses for all students to develop into the credit management, improving the teaching methods, enhance actual effect. Adhere to the combination of theory and practice, organize students to participate in all kinds of innovation and entrepreneurship competition, entrepreneurship simulation and other practical activities, focus on training students' innovation, entrepreneurship and innovation and entrepreneurship. Colleges and universities should establish flexible educational system, allowing students drop out of business. Universities to hire entrepreneurs, entrepreneurs, investors, experts and scholars as part of a part-time tutor, a guide to innovation and entrepreneurship students.

Two is to guide the college graduates to the grassroots employment. Colleges and universities to further improve the service support to encourage graduates to the grassroots employment mechanism, the implementation and improvement of tuition compensation and student loan compensation, follow-up studies and employment services and other policies. To continue to jointly with the relevant departments, the good organization and implementation of special post planned rural teachers' "western plan" "university student village officer" "three help" and so on various types of basic services project, through regular visits, tracking training concerned graduate jobs, growth and development. Actively cooperate with the Department of political science and law, study and formulate sound from politics and law graduates recruiting talent to normative and convenient mechanism of specific measures, to promote the employment of law graduates.

Three is to strengthen the employment guidance services. Colleges and universities should establish a sound professional development and employment guidance service system. Strengthen employment guidance courses and disciplines, combined with the current economic development of new formats and new normal, timely disciplines dynamic and industry development achievements into classroom teaching, to improve the classroom teaching engagement and attractive. Depth personalized guidance and counseling, help students establish reasonable career goals, timely dredge graduates anxiety, dependence and other psychological problems, and enhance the compressive strength of the coping with competition and frustration. Actively organize the professional planning competition, professional experience and other extracurricular activities, and give full play to the leading role of the employment practice, to further improve the coverage and effectiveness of the employment guidance.

Four is to further strengthen the ideological education and policy advocacy. Around the colleges and universities the ideological education as a means to promote employment and entrepreneurship pioneering work, actively organize graduates in-depth study and understand the series of important speech of General Secretary Xi Jinping and give graduates reply spirit, to cultivate and practice the socialist core values, guide the graduates to personal dream into the great practice of the Chinese dream, take the initiative to in underdeveloped areas of the country needs. To be combined with the characteristics of the young students, organize and guide graduates in-depth and rural organizations and the frontline of production practice, promote their knowledge conditions, grounding, turn the idea, long ability. To speak through the outstanding alumni experience, experts and scholars to talk about the situation, a variety of forms of business experience, such as experience, to help graduates adjust employment expectations, planning professional career, active employment and entrepreneurship.

Five is to promote higher education to better meet the needs of economic and social development. To all colleges and universities in order to improve the quality as the core, structure adjustment as a breakthrough, accelerate and promote the comprehensive reform of higher education, and further optimize the regional layout structure, culture level structure and the structure of subjects and majors. To guide a group of ordinary undergraduate colleges and universities to the application of technological transformation and development, continue to expand the type and scale of professional degree graduate students. Professional warning improves the exit and dynamic adjustment mechanism, timely to reduce employment rate continued lower professional enrollment plan, make the discipline and specialty structure and the development of economy and society needs to adapt, and employment docking. Explore establish harmonious mechanism of employment of graduates of colleges and universities and key industry talent supply and demand, and promote the school cooperation, school, school enterprise docking, the construction of colleges and universities with the relevant departments, research institutes, industry enterprise collaborative education system. Promote college students to participate in various forms of practice training, social practice and volunteer activities, enhance the ability of employment and entrepreneurship.

Six is to strengthen the employment and entrepreneurship organization and leadership. Colleges and universities to continue to work on the university graduates employment in a prominent position, strengthen the organization and leadership, improve the responsibility system, a clear division of labor, and promote the work. To innovate the service mode and means, strengthen the supervision and inspection and guidance, and timely study and solve the new situation and new problems in the work. Should be combined with the actual situation of local schools, and effectively increase the intensity of investment in employment and entrepreneurship, the development of more effective policy measures to ensure the completion of the work objectives and tasks.

\section{MAKE UP FOR THE DISADVANTAGES OF QUALITY- ORIENTED EDUCATION IN CURRENT EMPLOYMENT SITUATION}

\section{A. The heavy professional skills to comprehensive quality}

School education goal should be to cultivate students comprehensive quality, therefore, must update education idea; Improve and improve teachers' comprehensive quality; Curriculum structure reform, the teaching innovation; Implement credit system primarily, studio system and academic year system as the auxiliary teaching management 
mode; Reform education method and the way of classroom teaching, enrich the teaching means. For a liberal education, interdisciplinary and related disciplines, pay attention to line with the market economy, develop the students' intelligence, ability, provide students with a broad view of knowledge space, training vision broad generalist rather than narrow-minded, in addition to the bank, what all don't understand.

From the entire education system and the design for the understanding of the design education for more than 20 years development, China's design is obvious in the "market affects" mode, rather than "thought affects", "social affects" mode. Until today, the design of domestic education although the surface is very busy, in fact in the education system and there is no essential difference in the early $1980 \mathrm{~s}$. Many people think that adds some computer courses is the modernization of education, is just to learn a few software operation, the progress of social economy is not reflected from the art design education.

\section{B. To strengthen the construction of teaching staff, improve the structure of teachers}

Improve the art of art teachers' education level and comprehensive quality; establish a high quality academic echelon

Build a high-quality teachers team with a group in the artistic creation and academic study of the impact of the international leader, is the key to the construction of first-class art academy [8]. Art teachers compared with other natural science and humanities teacher Education is generally low. The western developed country to teacher's art colleges' degree generally requires a doctorate. Although degree is not fully cover the person of ability, but the degree and degree reflects a person's professional quality, at least degree, degree is higher, the starting point of work is relatively higher.

Art design in colleges and universities teachers solve, in part, by their colleges and universities graduates teaches or introduce other art design colleges and universities graduates directly as a teacher, although this part of the teachers' degree is higher, now generally requires a master's degree or above, but the title on the low side, lack of experience in teaching, the teaching level be discounted; Others from fine arts career of art design, this part of the teachers use short-term training, more training or self-study way into art and design, no professional art design education, also do not have practice experience in art design, most people are hard to work of art and design teaching.

\section{Adapt to the need of society, to cultivate practical talents}

The job market competition is intense; enterprise design graduates can enter the role as soon as possible. The design of the school education must as far as possible with the enterprise cohesion to the designer's specific request, in addition to meet the needs of the enterprise on the curriculum, school should pay special close cooperation with enterprises, and enterprises to jointly develop products, encourage students to enterprises to carry out a long-term internship, to know the detailed workings of enterprise product design; The design of the student subject is usually from companies.

Graduate employment service work in schools of different levels should pay attention to both, especially in the economic relatively developed area broaden the employment channels, provide students with good jobs and services, efforts to make the art design education advantage and obtain the sustained, stable development and improve quality.

\section{CONCLUSION}

University quality education and vocational and technical schools at different levels of skill education difference between quality educations. Vocational and technical schools to professional education is given priority to, complementary with quality-oriented education; And university education to pay equal attention to both, and even greater demands of the quality education, is not only to "learning" and "know how". The socalled "teach them to fish, as teach them to fish", do not put the cart before the horse. Education itself is a theory of the discipline, and practice of the discipline, we can not only heavy art professional technical training, skills and despise education teaching practice technical training.

\section{REFERENCES}

[1] Zheng Han. Transformation of Chinese Art Design Education [J]. JOURNAL of SHANGHAI INSTITUTE of applied TECHNOLOGY. In November, 2002:79-82 The Changing Art and Design Education of China [J]. JOURNAL of SHANGHAI INSTITUTE of TECHNOLOGY, Nov., 2002:79-82

[2] xu should shoot. Look from the academy of fine arts of Chinese and western history development in Chinese higher fine arts education present situation [D]. Nanjing normal university, master's degree thesis. 2007

[3] wei-dong meng. Institutions of higher learning of art design education question and countermeasure $[\mathrm{N}]$. The guangming daily, on August 3, 2007.

[4] less. Thinking about the present situation of art design education [N]. Journal of binzhou teachers college, 2003, 9.

[5] KouYan. Comparison of Art Design Education of China and The United States [J]. Journal of Nanchang Vocational and Technical Teachers College, 2002 (4) : 66-70 ms Kou Yan. The Comparision of The Education Between Chinese and American Art Design [J]. Journal of Nanchang Vocational \& Technical head 'College. The Apr., 2002:66-70

[6] liu chang. The current art design education present situation and the market demand $[\mathrm{J}]$. Science and technology entrepreneurship monthly, 2007, 9.

[7] wei-dong meng. Institutions of higher learning of art design education problems and countermeasures [N]. The guangming daily, on August 3, 2007.

[8] Jin Mei. Chinese Higher Fine arts Education Reform Model Study [J]. Journal of MANAGEMENT REVIEW. 2009 (8) : 80-85 Jin Mei. A Study on the Reform Model of China who Fine Art Education [J]. Journal of MANAGEMENT REVIEW, No. 8 (2009) 